Article

\title{
Clinical Relevance of Collagen Protein Degradation Markers C3M and C4M in the Serum of Breast Cancer Patients Treated with Neoadjuvant Therapy in the GeparQuinto Trial
}

\author{
Malgorzata Banys-Paluchowski ${ }^{1}$, Sibylle Loibl ${ }^{2}$, Isabell Witzel ${ }^{3}$, Christoph Mundhenke ${ }^{4}$, \\ Bianca Lederer ${ }^{2} \mathbb{D}$, Christine Solbach ${ }^{5}$, Thomas Karn ${ }^{5} \mathbb{D}$, Frederik Marmé ${ }^{6}$, \\ Valentina Nekljudova ${ }^{2}$, Christian Schem ${ }^{7}$, Elmar Stickeler ${ }^{8}$, Nicholas Willumsen ${ }^{9}$, \\ Morten A. Karsdal ${ }^{9}$, Michael Untch ${ }^{10}$ and Volkmar Müller ${ }^{3, *}$ \\ 1 Department of Gynecology and Obstetrics, Asklepios Klinik Barmbek, 22307 Hamburg, Germany \\ German Breast Group, 63263 Neu-Isenburg, Germany \\ Department of Gynecology, University of Hamburg-Eppendorf, 20251 Hamburg, Germany \\ Department of Gynecology and Obstetrics, University of Kiel, 24105 Kiel, Germany \\ Department of Gynecology and Obstetrics, University of Frankfurt, 60590 Frankfurt am Main, Germany \\ 6 University Hospital Mannheim, Medical Faculty Mannheim of the Heidelberg University, \\ 68167 Mannheim, Germany \\ 7 Mammazentrum Hamburg, 20357 Hamburg, Germany \\ 8 Department of Gynecology and Obstetrics, RWTH Aachen University, 52074 Aachen, Germany \\ 9 Nordic Bioscience, Biomarkers and Research, 2730 Herlev, Denmark \\ 10 Department of Gynecology and Obstetrics, Helios Klinikum Berlin-Buch, 13125 Berlin, Germany \\ * Correspondence: v.mueller@uke.de; Tel.: +49-40-7410-52510
}

Received: 29 July 2019; Accepted: 14 August 2019; Published: 15 August 2019

Abstract: Background: Remodeling of extracellular matrix through collagen degradation is a crucial step in the metastatic cascade. The aim of this study was to evaluate the potential clinical relevance of the serum collagen degradation markers (CDM) C3M and C4M during neoadjuvant chemotherapy for breast cancer. Methods: Patients from the GeparQuinto phase 3 trial with untreated HER2-positive operable or locally advanced breast cancer were enrolled between 7 November 2007, and 9 July 2010, and randomly assigned to receive neoadjuvant treatment with $\mathrm{EC} /$ docetaxel with either trastuzumab or lapatinib. Blood samples were collected at baseline, after four cycles of chemotherapy and at surgery. Cutoff values were determined using validated cutoff finder software (C3M: Low $\leq 9.00 \mathrm{ng} / \mathrm{mL}$, high $>9.00 \mathrm{ng} / \mathrm{mL}$, C4M: Low $\leq 40.91 \mathrm{ng} / \mathrm{mL}$, high $>40.91 \mathrm{ng} / \mathrm{mL}$ ). Results: 157 patients were included in this analysis. At baseline, $11.7 \%$ and $14.8 \%$ of patients had high C3M and C4M serum levels, respectively. No correlation was observed between CDM and classical clinical-pathological factors. Patients with high levels of CDM were significantly more likely to achieve a pathological complete response (pCR, defined as ypT0 ypN0) than patients with low levels (C3M: $66.7 \%$ vs. $25.7 \%, p=0.002$; C4M: $52.7 \%$ vs. $26.6 \%, p=0.031$ ). Median levels of both markers were lower at the time of surgery than at baseline. In the multivariate analysis including clinical-pathological factors and C3M levels at baseline and changes in C3M levels between baseline and after four cycles of therapy, only C3M levels at baseline ( $p=0.035$, OR $4.469,95 \%-C I$ 1.115-17.919) independently predicted $\mathrm{pCR}$. In a similar model including clinical-pathological factors and C4M, only C4M levels at baseline $(p=0.028$, OR 6.203, $95 \%$-CI 1.220-31.546) and tumor size ( $p=0.035$, OR 4.900,95\%-CI 1.122-21.393) were independent predictors of $\mathrm{pCR}$. High C3M levels at baseline did not correlate with survival in the entire cohort but were associated with worse disease-free survival (DFS; $p=0.029,5$-year DFS $40.0 \%$ vs. $74.9 \%$ ) and overall survival (OS; $p=0.020$, 5-year OS $60.0 \%$ vs. $88.3 \%$ ) in the subgroup of patients randomized to lapatinib. In the trastuzumab arm, C3M did not correlate with survival. In the entire patient cohort, high levels of C4M at baseline were significantly associated with shorter DFS ( $p=0.001,5$-year DFS 
$53.1 \%$ vs. $81.6 \%$ ) but not with OS. When treatment arms were considered separately, the association with DFS was still significant ( $p=0.014,5$-year DFS $44.4 \%$ vs. $77.0 \%$ in the lapatinib arm; $p=0.023$, 5 -year DFS $62.5 \%$ vs. $86.2 \%$ in the trastuzumab arm). Conclusions: Collagen degradation markers are associated with response to neoadjuvant therapy and seem to play a role in breast cancer.

Keywords: breast cancer; C3M; C4M; collagen degradation marker; neoadjuvant therapy; trastuzumab; lapatinib

\section{Introduction}

The interaction between cancer cells and their microenvironment is considered a crucial factor in the metastatic cascade, allowing tumor cells to proliferate, build new vessels, leave the primary tumor bed and finally enter and persist at secondary homing sites. The non-cellular part of the tumor microenvironment, the extracellular matrix (ECM), consists of a variety of macromolecules, such as collagen and glycoproteins [1]. While the basement membranes of the ECM are formed mostly by type IV collagen, type I and type III collagen are the most abundant proteins of the underlying interstitial matrix. ECM undergoes constant remodeling, mediated mainly by matrix-metalloproteinases (MMP), and in the healthy tissue, matrix degradation is balanced by protein formation. This controlled homeostasis is assumed to be disrupted during cancer development and progression [2].

In the process of MMP-mediated ECM degradation, small fragments of ECM turnover products are generated and released into the bloodstream. Several studies have shown that serum levels of collagen degradation fragments are elevated in cancer patients compared to healthy controls $[3,4]$. Bager et al. found levels of MMP-degraded collagen type I, III and IV (i.e., C1M, C3M and C4M, respectively) to be 1.5 to 6-fold higher in ovarian and breast cancer patients than in controls [3]. Similarly, elevated levels of serum biomarkers reflecting altered collagen turnover have been reported in colorectal and lung cancer as well as melanoma [5,6]. In pancreatic cancer, a combined panel of serum collagen degradation markers was able to differentiate patients from healthy controls with a high diagnostic power [7].

So far, evidence regarding the prognostic significance of soluble ECM turnover markers is still limited. Recently, Lipton et al. showed that elevated levels of MMP-generated collagen fragments in the serum of metastatic breast cancer patients were associated with shorter time to progression and overall survival [8]. In a Danish register-based study, C1M but not C4M was predictive of survival in postmenopausal women diagnosed with any cancer within 3 years of blood sampling [9]. However, no study has focused on the role of collagen degradation fragments in women with early breast cancer.

The aims of the present study were 1) to assess the clinical relevance of serum C3M and C4M in patients with HER2-positive breast cancer scheduled to receive neoadjuvant therapy and 2) to examine the changes of these markers during systemic treatment.

\section{Results}

\subsection{Serum Levels of Collagen Degradation Markers}

A total of 615 HER2-positive patients were treated in the GeparQuinto trial (Figure 1). Out of these, 157 patients were included in this substudy and provided blood samples (Figure 2). Arms were well balanced with no significant differences between patients treated with trastuzumab and lapatinib regarding age or tumor characteristics (Appendix A Table A1). 


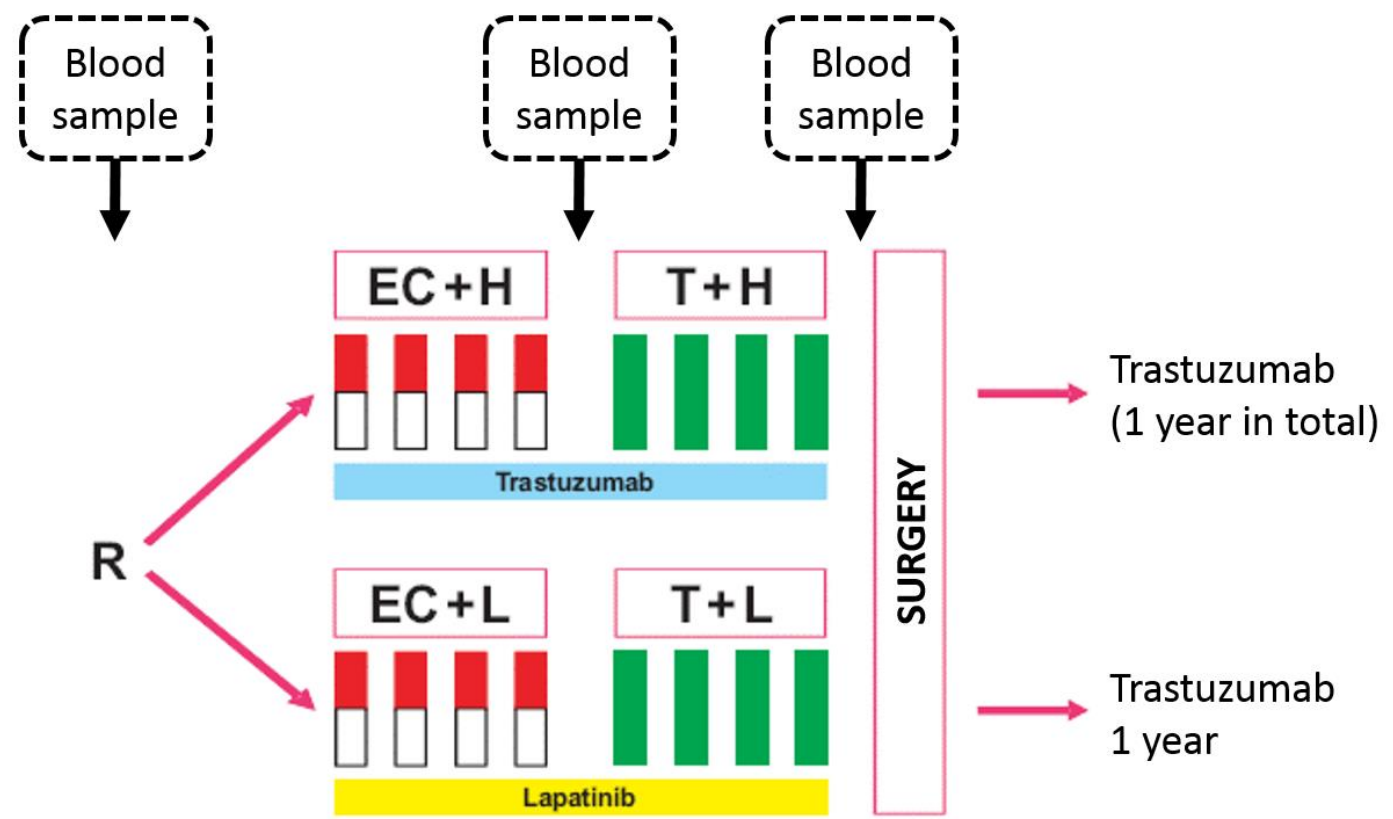

Figure 1. Serum collection in the HER2-positive cohort in the GeparQuinto trial.Abbreviations: EC-epirubicin/cyclophosphamide, T-docetaxel, H-trastuzumab, L-lapatinib.

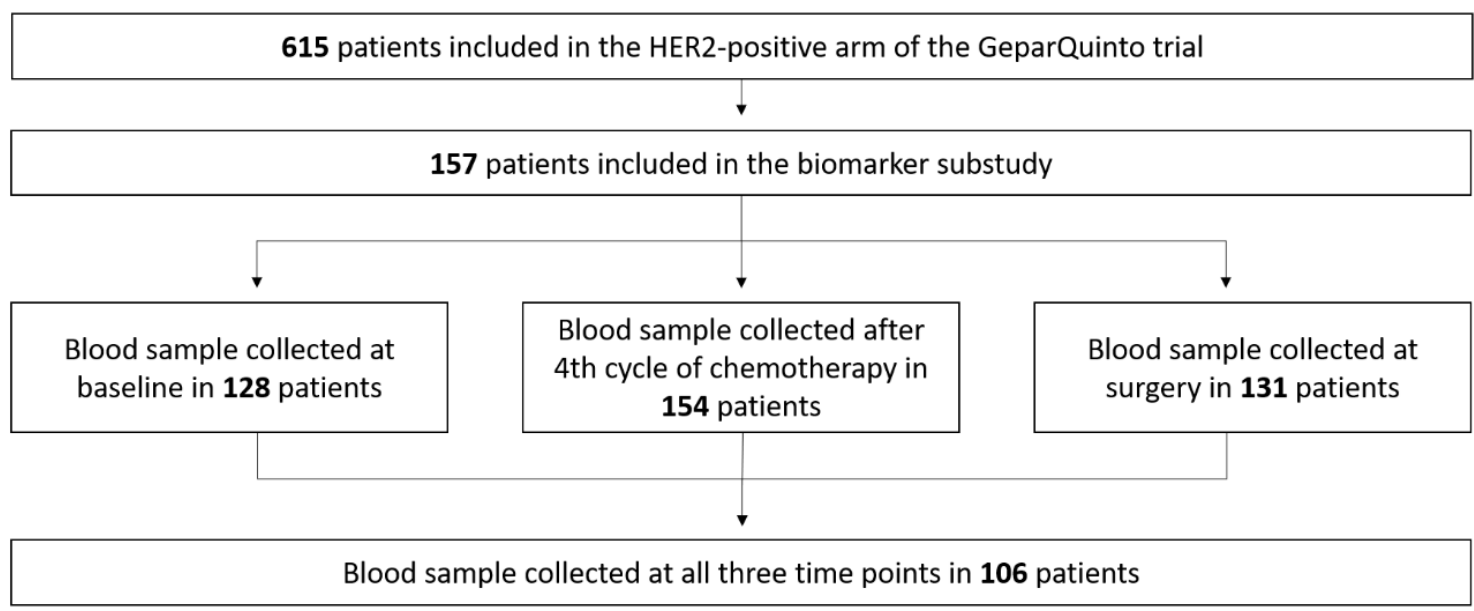

Figure 2. Flow diagram showing the number of patients with a blood sample collected at different time points.

At baseline, levels of collagen degradation markers $\mathrm{C} 3 \mathrm{M}$ and $\mathrm{C} 4 \mathrm{M}$ were determined in 128 patients (Figure 2). A total of 15 out of 128 patients (12\%) had high C3M levels (i.e., $>9.004 \mathrm{ng} / \mathrm{mL}$ ) and 19 out of 128 patients $(15 \%)$ had high C4M levels (i.e., $>40.91 \mathrm{ng} / \mathrm{mL}$ ). Clinical-pathological data are summarized in Table 1. Compared to serum levels in patients, healthy females had lower levels of both C3M and C4M (C3M: Median 6.4 vs. $3.6 \mathrm{ng} / \mathrm{mL}$; C4M: Median 31.9 vs. $25.3 \mathrm{ng} / \mathrm{mL}$, respectively). Levels of collagen degradation markers in breast cancer patients did not correlate with established clinical-pathological factors such as hormone receptor status or grading (Table 1). 
Table 1. Correlation between collagen degradation marker levels in the serum at baseline and clinical-pathological, treatment and outcome variables.

\begin{tabular}{|c|c|c|c|c|c|c|c|}
\hline \multirow{2}{*}{ Parameter } & \multirow{2}{*}{ Total } & \multicolumn{3}{|c|}{$\mathrm{C} 3 \mathrm{M}$} & \multicolumn{3}{|c|}{$\mathrm{C} 4 \mathrm{M}$} \\
\hline & & High C3M n (\%) & Low C3M n (\%) & $p$-Value ${ }^{1}$ & High C4M n (\%) & Low C4M n (\%) & $p$-Value ${ }^{1}$ \\
\hline Overall & 128 & $15(11.7 \%)$ & $113(88.3 \%)$ & & $19(14.8 \%)$ & $109(85.2 \%)$ & \\
\hline$>50$ years & 66 & $8(12.1 \%)$ & $58(87.9 \%)$ & \multirow[b]{2}{*}{1.000} & $10(15.2 \%)$ & $56(84.8 \%)$ & \multirow{2}{*}{1.000} \\
\hline$\leq 50$ years & 62 & $7(11.3 \%)$ & $55(88.7 \%)$ & & $9(14.5 \%)$ & $53(85.5 \%)$ & \\
\hline \multicolumn{8}{|l|}{ cT stage } \\
\hline \multicolumn{8}{|l|}{ cN stage } \\
\hline cNO & 51 & $6(11.8 \%)$ & $45(88.2 \%)$ & \multirow[b]{2}{*}{1.000} & $6(11.8 \%)$ & $45(88.2 \%)$ & \multirow[b]{2}{*}{0.455} \\
\hline $\mathrm{cN}+$ & 75 & $9(12.0 \%)$ & $66(88.0 \%)$ & & $13(17.3 \%)$ & $62(82.7 \%)$ & \\
\hline \multicolumn{8}{|c|}{ Estrogen receptor status } \\
\hline Positive & 64 & $5(7.8 \%)$ & $59(92.2 \%)$ & 0.271 & $8(12.5 \%)$ & $56(87.5 \%)$ & 0.620 \\
\hline Negative & 75 & $12(16.0 \%)$ & $63(84.0 \%)$ & 0.096 & $12(16.0 \%)$ & $63(84.0 \%)$ & 0.802 \\
\hline \multicolumn{8}{|l|}{ Grading } \\
\hline G1-2 & 65 & $5(7.7 \%)$ & $60(92.3 \%)$ & \multirow[t]{2}{*}{0.177} & $7(10.8 \%)$ & $58(89.2 \%)$ & \multirow[t]{2}{*}{0.220} \\
\hline G3 & 63 & $10(15.9 \%)$ & $53(84.1 \%)$ & & $12(19.0 \%)$ & $51(81.0 \%)$ & \\
\hline \multicolumn{8}{|c|}{ Anti-HER2 therapy } \\
\hline Lapatinib & 63 & $6(9.5 \%)$ & $57(90.5 \%)$ & \multirow[t]{2}{*}{0.585} & $9(14.3 \%)$ & $54(85.7 \%)$ & \multirow[t]{2}{*}{1.000} \\
\hline Trastuzumab & 65 & $9(13.8 \%)$ & $56(86.2 \%)$ & & $10(15.4 \%)$ & $55(84.6 \%)$ & \\
\hline \multicolumn{8}{|l|}{$\mathrm{pCR}$} \\
\hline Yes & 39 & $10(25.6 \%)$ & $29(74.4 \%)$ & \multirow[t]{2}{*}{0.002} & $10(25.6 \%)$ & $29(74.4 \%)$ & \multirow[t]{2}{*}{0.031} \\
\hline No & 89 & $5(5.6 \%)$ & $84(94.4 \%)$ & & $9(10.1 \%)$ & $80(89.9 \%)$ & \\
\hline
\end{tabular}

${ }^{1}$ Fisher's Exact Test (2-sided). Abbreviations: pCR-pathological complete response.

Further measurements of collagen degradation markers were conducted after four cycles of neoadjuvant chemotherapy with epirubicin and cyclophosphamide and at surgery. Median levels of both markers at surgery were lower than at baseline (Table 2). Interestingly, while median levels of C3M were lower after four cycles than before the start of treatment, we observed an initial increase in median C4M levels between baseline and after four cycles of therapy. C3M and C4M levels increased between baseline and after four therapy cycles in $44.4 \%$ and $52.9 \%$ of patients, respectively. The proportion of patients with an increase in C3M levels between baseline and after four cycles was comparable in the trastuzumab and lapatinib arm ( $44 \%$ and $45 \%$, respectively), while more patients experienced an increase in C4M levels when treated with trastuzumab than lapatinib (58\% vs. $48 \%$, respectively).

An increase of at least $20 \%$ in serum C3M and C4M levels between baseline and surgery was seen in $23 \%$ and $24 \%$ of patients, respectively (Table 3), whereas serum levels declined by at least $20 \%$ in $37 \%$ in case of $\mathrm{C} 3 \mathrm{M}$ and $22 \%$ in case of C4M. The changes in serum marker levels were similar between treatment arms. 
Table 2. Levels of C3M and C4M in the serum at different time points.

\begin{tabular}{|c|c|c|c|c|c|c|c|}
\hline \multirow{2}{*}{$\begin{array}{l}\text { Time Point of Blood } \\
\text { Sampling }\end{array}$} & \multirow{2}{*}{ Value } & \multicolumn{3}{|c|}{ C3M (ng/mL) } & \multicolumn{3}{|c|}{ C4M (ng/mL) } \\
\hline & & Total & Trastuzumab Arm & Lapatinib Arm & Total & TRASTUZUMAB ARM & Lapatinib Arm \\
\hline \multirow{3}{*}{ Baseline } & Median & 6.364 & 6.316 & 6.636 & 31.940 & 32.180 & 31.724 \\
\hline & Mean & 6.597 & 6.588 & 6.606 & 33.148 & 34.058 & 32.209 \\
\hline & Range & $1.640-17.236$ & $3.128-17.236$ & $1.640-12.264$ & $15.940-71.684$ & $15.940-71.684$ & $17.816-69.192$ \\
\hline \multirow{3}{*}{$\begin{array}{l}\text { After } 4 \text { cycles of } \\
\text { neoadjuvant therapy }\end{array}$} & Median & 6.100 & 6.036 & 6.172 & 33.664 & 33.856 & 33.304 \\
\hline & Mean & 6.295 & 6.148 & 6.435 & 34.500 & 34.246 & 34.740 \\
\hline & Range & $3.128-12.012$ & $3.128-11.388$ & $3.624-12.012$ & $14.020-87.176$ & $15.680-67.700$ & $14.020-87.176$ \\
\hline \multirow{3}{*}{ At time of surgery } & Median & 5.352 & 5.352 & 5.290 & 30.604 & 30.742 & 29.814 \\
\hline & Mean & 5.747 & 5.826 & 5.675 & 32.760 & 33.632 & 31.952 \\
\hline & Range & $1.724-14.316$ & $1.724-13.132$ & $2.496-14.316$ & $14.784-78.996$ & $18.416-70.060$ & $14.784-78.996$ \\
\hline
\end{tabular}

Table 3. Changes in serum levels of C3M and C4M between baseline and surgery according to treatment arm.

\begin{tabular}{ccccccc}
\hline Changes in Serum Levels & \multicolumn{3}{c}{ C3M n (\%) } & \multicolumn{3}{c}{ C4M n (\%) } \\
\hline & Total & Trastuzumab & Lapatinib & Total & Trastuzumab & Lapatinib \\
Increase $\geq 20 \%$ & $24(22.6 \%)$ & $12(23.1 \%)$ & $12(22.2 \%)$ & $25(23.6 \%)$ & $12(22.6 \%)$ & $13(24.5 \%)$ \\
No change ${ }^{1}$ & $43(40.6 \%)$ & $20(38.5 \%)$ & $23(42.6 \%)$ & $58(54.7 \%)$ & $29(54.7 \%)$ & $29(54.7 \%)$ \\
Decrease $\geq 20 \%$ & $39(36.8 \%)$ & $20(38.5 \%)$ & $19(35.2 \%)$ & $23(21.7 \%)$ & $12(22.6 \%)$ & $11(20.8 \%)$ \\
\hline
\end{tabular}

${ }^{1}$ defined as an increase $<20 \%$ or decrease $<20 \%$. 


\subsection{Collagen Degradation Markers and Response to Therapy}

Patients with elevated serum levels of C3M and C4M were significantly more likely to achieve pathological complete response (pCR). Out of 15 patients with high C3M levels at baseline, ten $(66.7 \%)$ achieved pCR, compared to 29 out of $113(25.7 \%)$ patients with low levels $(p=0.002$, whereas 10 out of $19(52.6 \%)$ of patients with high C4M levels and 29 out of $109(26.6 \%)$ of patients with low C4M levels achieved $\mathrm{pCR}(p=0.031)$ (Table 1$)$. In the multivariate analysis including pre-chemotherapy tumor size, nodal status, grading, hormone receptor status, C3M levels at baseline and changes in C3M levels between baseline and after four cycles of therapy, only C3M levels at baseline ( $p=0.035$, OR 4.469, 95\%-CI 1.115-17.919) independently predicted pCR. In a multivariate model including pre-chemotherapy tumor size, nodal status, grading, hormone receptor status, C4M levels at baseline and changes in C4M levels between baseline and after four cycles of therapy, only C4M levels at baseline ( $p=0.028$, OR 6.203, 95\%-CI 1.220-31.546) and tumor size $(p=0.035$, OR $4.900,95 \%-C I$ 1.122-21.393) were independent predictors of pCR.

\subsection{Collagen Degradation Markers and Survival}

After a median follow up of 60.6 months, 14 patients died and 34 were diagnosed with a relapse. High C3M levels at baseline did not correlate with survival in the entire cohort (Figure 3, Table 4) but were associated with worse disease-free survival (DFS; $p=0.029$, 5-year DFS $40.0 \%$ vs. $74.9 \%$ ) and overall survival (OS; $p=0.020$, 5-year OS $60.0 \%$ vs. $88.3 \%$ ) in the subgroup of patients randomized to lapatinib. In the trastuzumab arm, C3M did not correlate with survival (DFS: $p=0.775,5$-year DFS $75.0 \%$ vs. $84.2 \%$; OS: $p=0.678,5$-year OS $87.5 \%$ vs. $91.7 \%$ ). In the entire patient cohort, high levels of C4M at baseline were significantly associated with shorter DFS but not with OS (Figure 4, Table 4). When treatment arms were considered separately, the association with DFS was still significant ( $p=0.014$ and 5-year DFS $44.4 \%$ vs. $77.0 \%$ in the lapatinib arm; $p=0.023$ and 5-year DFS $62.5 \%$ vs. $86.2 \%$ in the trastuzumab arm).

A decline of at least $20 \%$ in serum levels of C3M between baseline and after four cycles of therapy predicted significantly shorter DFS $(p=0.004$, HR 3.55, 95\%-CI 1.51-8.31) and OS ( $p=0.022$, HR 6.49, 95\%-CI 1.31-32.23) (Figure 5, Appendix A Table A2). No association between changes in C4M levels and survival were observed.
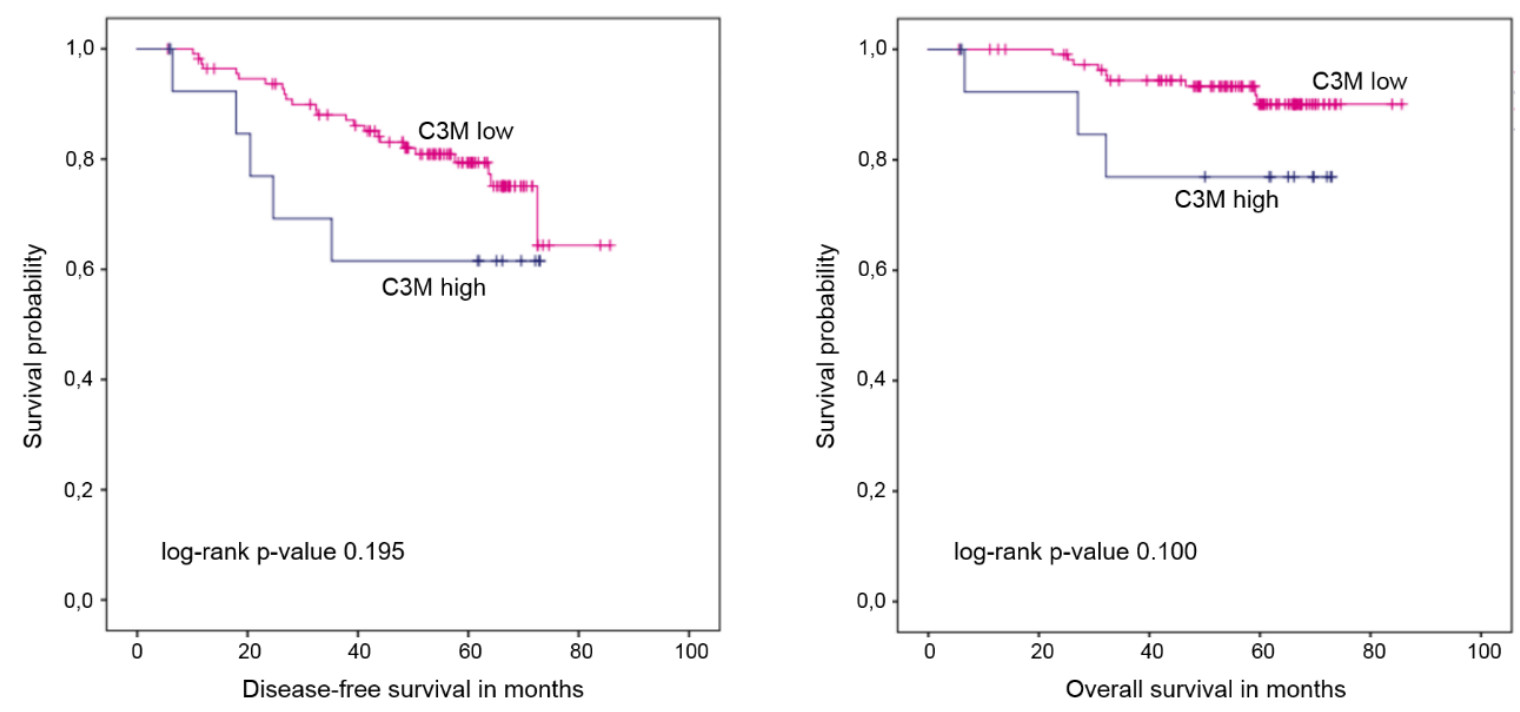

Figure 3. Kaplan-Meier plots of disease-free and overall survival stratified by C3M levels at baseline. 
Table 4. Survival times in correlation with C3M and C4M levels at baseline.

\begin{tabular}{|c|c|c|c|}
\hline \multicolumn{2}{|c|}{ Endpoint } & $\begin{array}{c}\text { C3M } \\
\text { High vs. Low }\end{array}$ & $\begin{array}{c}\text { C4M } \\
\text { High vs. Low }\end{array}$ \\
\hline \multirow{5}{*}{$\begin{array}{l}\text { Disease-free } \\
\text { survival }\end{array}$} & Median & Not reached vs. not reached & 63.7 months vs. not reached \\
\hline & Mean & $\begin{array}{l}53.0(95 \%-C I 38.9-67.1) \text { vs. } 72.2 \\
(95 \%-C I \text { 67.2-77.2) months }\end{array}$ & $\begin{array}{c}49.5(95 \%-C I ~ 37.9-61.0) \text { vs. } \\
74.0(95 \%-C I \text { 69.2-8.8) months }\end{array}$ \\
\hline & Log rank $p$-value & 0.195 & 0.001 \\
\hline & 5-year DFS & $61.5 \%$ vs. $79.4 \%$ & $53.1 \%$ vs. $81.6 \%$ \\
\hline & HR (95\% CI), $p$-value & $1.88(0.71-4.95), p=0.202$ & $3.39(1.54-7.45), p=0.002$ \\
\hline \multirow{5}{*}{$\begin{array}{l}\text { Overall } \\
\text { survival }\end{array}$} & Median & Not reached vs. not reached & Not reached vs. not reached \\
\hline & Mean & $\begin{array}{l}61.2(95 \%-C I \text { 49.2-73.3) vs. } 81.2 \\
(95 \%-C I ~ 78.4-84.0) \text { months }\end{array}$ & $\begin{array}{l}64.0(95 \%-C I \text { 54.8-73.3) vs. } 81.0 \\
(95 \%-C I \text { 78.1-84.0) months }\end{array}$ \\
\hline & Log rank $p$-value & 0.100 & 0.252 \\
\hline & 5-year OS & $76.9 \%$ vs. $90.1 \%$ & $82.6 \%$ vs. $89.8 \%$ \\
\hline & HR (95\% CI), $p$-value & $2.86(0.77-10.57), p=0.116$ & $2.11(0.57-7.80), p=0.263$ \\
\hline
\end{tabular}

Abbreviations: DFS-disease-free survival; HR-hazard ratio; OS-overall survival.
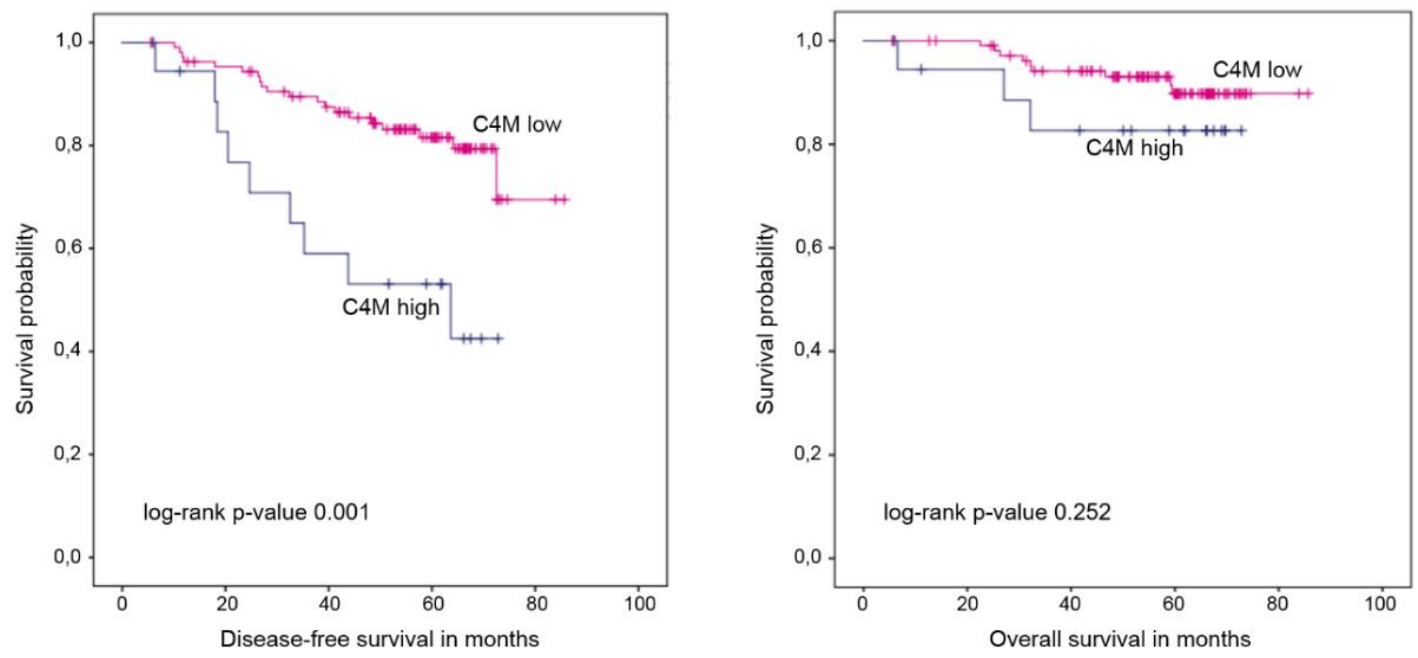

Figure 4. Kaplan-Meier plots of disease-free and overall survival stratified by C4M levels at baseline.
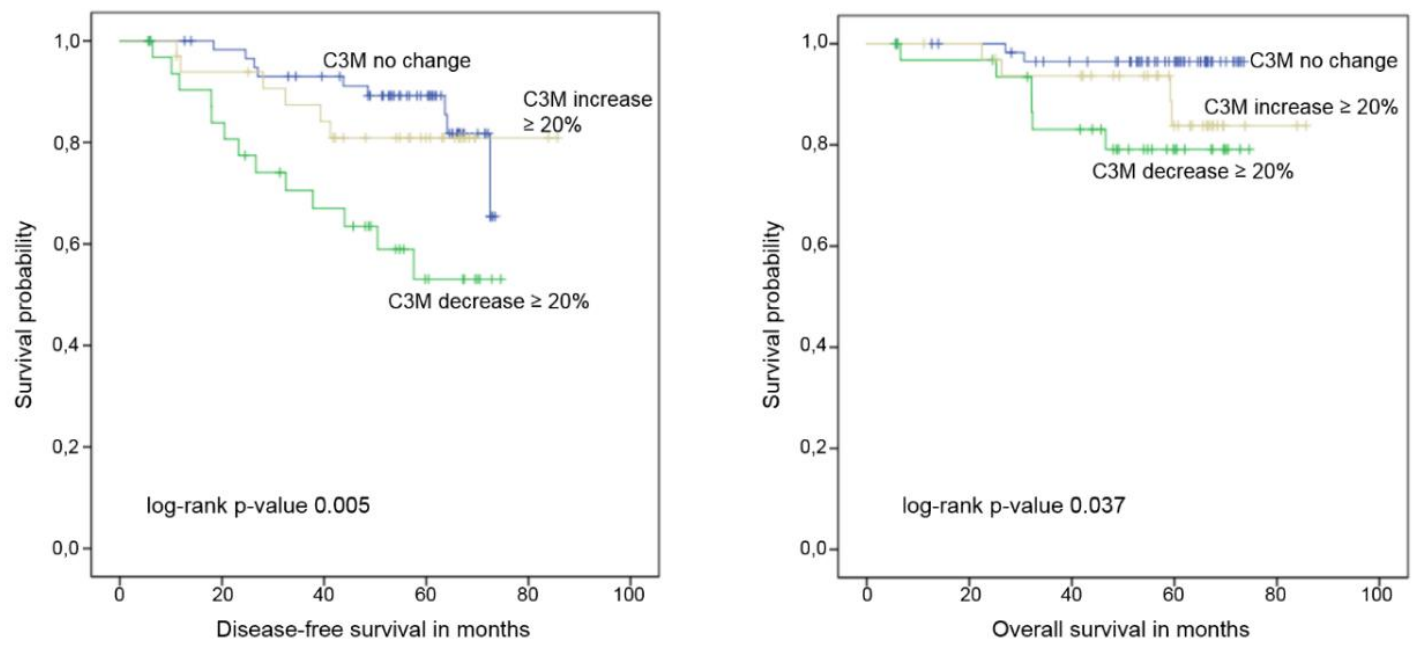

Figure 5. Kaplan-Meier plots of disease-free and overall survival stratified by changes in C3M levels between baseline and after four cycles of therapy ('no change' is defined as an increase or decrease $<20 \%$ ). 


\section{Discussion}

To the best of our knowledge, this is the first study to examine collagen degradation markers in the serum of patients undergoing neoadjuvant therapy for breast cancer. At baseline, patients showed higher levels of C3M and C4M than healthy controls. This is in accordance with previous studies. Bager et al. investigated biomarkers reflecting altered MMP-mediated collagen turnover and reported significantly lower levels of both serum markers in healthy women than in breast and ovarian cancer patients [3], suggesting that the tightly controlled homeostasis of the ECM can be severely disturbed by malignant growth. Indeed, alterations of the microenvironment seem to play a crucial role in cancer development and progression. While the major fibrillar collagens have a relatively slow metabolic turnover in histologically normal breast tissue and in benign lesions, increased expression of various types of procollagen mRNAs was reported in the fibroblastic cells of the stroma surrounding breast cancer cells [10]. A comprehensive gene expression portrait of cells composing breast tissue in situ and invasive breast carcinomas showed significant changes in gene expression profile in all cell types during tumor progression, indicating that the microenvironment actively participates in cancer growth and invasion [11].

Interestingly, baseline levels of collagen degradation markers did not correlate with clinical-pathological factors. However, all patients included in the present analysis had HER2-positive disease since the trial was aimed at comparing trastuzumab and lapatinib in the neoadjuvant setting. Whether serum levels of ECM-related biomarkers differ between tumor subtypes, remains therefore unclear. Previously, Bergamaschi et al. showed in a microarray-based study that tumors can be divided into four subgroups based on the expression of the components of extracellular matrix and that these ECM signatures showed low correlation with five intrinsic subtypes [12]. In the group of patients with luminal tumors assessment of ECM signature identified those with a particularly poor prognosis. In addition, it has been hypothesized that HER2-mediated pathways may influence ECM degradation. Data from gastric and breast cancer suggest a cross-talk between various members of ECM and HER2. In a gastric cancer study, HER2 knockdown led to downregulation of the expression of MMP-1, while HER2 overexpression enhanced the transcription of MMP-1 through the activation of a specific promoter [13]. In breast cancer (BC), the addition of MMP-9 to cell lines resulted in a significant rise in HER2 expression, indicating that some MMPs may serve as regulators of HER2 expression on human epithelial cells [14]. Another important finding is the observation that a large proportion of patients with HER2-positive BC develop resistance to trastuzumab and this might be due to the loss of expression of HER2 extracellular domain on tumor cells, caused by shedding/cleavage of HER2 by metalloproteinases [15].

Furthermore, in our study patients with elevated levels of C3M and C4M at baseline were significantly more likely to achieve a pathologically complete response. Previous studies have shown that tumor microenvironment can contribute to response or resistance to chemotherapeutic agents through different mechanisms [16]. For example, dense ECM can limit the blood flow and thus restrict access of the drug to parts of the tumor; further, interactions of tumor cells with ECM proteins may activate pro-survival signaling cascades leading to immediate drug protection or stromal cells may secrete pro-survival factors [17]. These mechanisms may allow tumor cells to survive long enough to acquire genetic changes leading to drug resistance. Jansen et al. examined tumor tissue from 112 patients with ER-positive metastatic BC treated with first-line tamoxifen and showed that six genes associated with the ECM (TIMP3, FN1, LOX, COL1A1, SPARC and TNC) were overexpressed in patients with resistant disease [18]. A translational substudy within the EORTC 10994/BIG 00-01 trial aimed at assessing the relevance of stromal cell expression in biopsy specimens before the start of neoadjuvant therapy with FEC [19]. The expression of stromal metagenes significantly predicted a response to therapy in this trial as well as in an independent cohort of ER-negative tumors from the M. D. Anderson Medical Center included in another neoadjuvant study [20]. However, in contrast to our trial, the above-mentioned studies focused on the ECM-related gene expression in tumor tissue and not on proteins in the blood. To the best of our knowledge, the only other study on the response to 
therapy and survival in the context of ECM degradations markers in breast cancer was conducted in the metastatic setting. Lipton et al. measured C1M, C3M, C4M and PRO-C3 in the pre-treatment serum of patients from a phase III randomized trial of 2nd-line endocrine therapy $(\mathrm{n}=148)$ and a 1st-line trastuzumab-treated cohort $(n=55)$ [8]. In the HR-positive cohort, higher C1M and C3M levels were associated with shorter time to progression; all fragments were associated with a shorter OS. In multivariate analysis for OS, higher levels of all fragments were significant for a reduced OS when added separately. In the HER2-positive cohort, higher levels of all fragments were associated with shorter time to progression; higher PRO-C3 was associated with a shorter OS. Indeed, patients with elevated levels of C3M and C4M in our study had numerically shorter DFS and OS, in case of C4M and OS the difference was statistically significant. Interestingly, higher levels of collagen degradation markers predicted both $\mathrm{pCR}$ and shorter survival in our study. While surprising at first, this observation suggests that a high turnover of the extracellular matrix is a typical feature of aggressive tumor behavior.

With regard to changes in serum degradation markers during systemic therapy, we show that levels of C3M and C4M decline between the start of treatment and surgery. Interestingly, a strong decline of C3M during the first four cycles of therapy was associated with worse clinical outcome. Possibly, this observation is confounded by the fact that patients with initially high levels of serum markers are more likely to experience a decline. This would further support our hypothesis that elevated levels of degradation markers reflect a more aggressive type of tumor. A small study investigated levels of collagen IV in the serum of 51 breast cancer patients undergoing neoadjuvant therapy and found these to be higher than in healthy controls [21]. Collagen IV levels increased during therapy but were not predictive of response to therapy. However, since we detected collagen degradation markers and not collagen levels, it is unclear how these older data should be interpreted in the light of our findings. Whether serum degradation markers or components of the extracellular matrix might serve as a potential therapeutic target, remains also unclear $[22,23]$.

The weak points of our analysis are the small sample size and the fact that serum samples at three predefined time points were not collected in all 157 potentially available patients. The participation in this substudy was voluntary and had no influence on the participation in the phase III clinical trial; further, there were other translational subprojects available. Secondly, all patients had HER2-positive tumors. The clinical trial GeparQuinto was designed to evaluate differences in the efficacy between trastuzumab and lapatinib. A marker able to identify patients who benefit more from a tyrosine kinase inhibitor like lapatinib would be of clinical relevance. We decided to examine two known collagen degradation markers because these were deemed most promising in the context of predicting therapy response. However, levels of degradation markers in the serum did not predict which HER2-targeted therapy the patients are most likely to benefit from.

\section{Materials and Methods}

The design of the GeparQuinto phase 3 trial (NCT00567554, EudraCT registration number 2006-005834-19) was described in detail elsewhere [24-26]. Briefly, patients with untreated HER2-positive operable or locally advanced breast cancer were enrolled between 7 November 2007, and 9 July 2010 and randomly assigned to receive neoadjuvant treatment with four cycles of EC (epirubicin $90 \mathrm{mg} / \mathrm{m}^{2}$, cyclophosphamide $600 \mathrm{mg} / \mathrm{m}^{2}$, day 1, every 3 weeks) followed by four cycles of docetaxel $\left(100 \mathrm{mg} / \mathrm{m}^{2}\right.$, day 1, every 3 weeks) with either trastuzumab $(6 \mathrm{mg} / \mathrm{kg}$ intravenously, every 3 weeks, starting with a loading dose of $8 \mathrm{mg} / \mathrm{kg}$ ) or lapatinib (1250 mg per day) throughout all cycles before surgery. Patients completed 1 year of anti-HER2 treatment with trastuzumab after surgery in both treatment groups.

Blood samples were collected at three different time points: Before initiation of neoadjuvant therapy, after four cycles of EC and prior to surgery (Figure 1). Samples were stored at $-20^{\circ} \mathrm{C}$ and shipped on dry ice. All patients gave written informed consent to blood collection as part of the correlative science program, before entering the study. Participation in the clinical trial was still possible even if a patient did not agree to participate in the translational research project. The biomarker 
investigations in the GeparQuinto study were performed after approval by the Institutional Review Board (IRB) (Registration number: 4 December 2007, Ethics commission of the special field "Medicine" at the Goethe University Frankfurt, Germany; EudraCT number: 2006-005834-19; Date of registration: 12 April 2007). Samples from healthy controls included blood samples from 19 females and were part of a previously published study (Appendix A Table A3) [27].

Trial registration: NCT00567554, EudraCT registration number 2006-005834-19. This study was conducted by the German Breast Group and the AGO-Breast.

\subsection{Quantitative Analysis of C3M and C4M}

Serum markers were measured using a competitive Enzyme-Linked Immune Sorbent Associated (ELISA) assay (Nordic Bioscience, Herlev, Denmark) according to the manufacturer's specifications. The validation steps for these assays have been described in detail previously $[28,29]$. Since C3M and C4M are generated by different MMPs, they specifically reflect MMP-mediated degradation of type III and type IV collagen, respectively. Each collagen fragment has a specific protease-generated neo-epitope (cleavage site) present against which the individual immuno-assay is highly specific. The intraassay and interassay variations were $<10 \%$ and $<15 \%$, respectively.

\subsection{Statistical Analysis}

Fisher's Exact Test was used to examine the relationship between C3M/C4M levels and other parameters, such as clinical and histological factors. Univariate and multivariate logistic regressions were used to determine odds ratios and $95 \% \mathrm{CI}$ for pCR (defined as ypT0 ypN0) according to the biomarker.

A publicly available Cutoff Finder software (http://molpath.charite.de/cutoff/) was used to convert the continuous variables into dichotomous variables with the outcome variable $\mathrm{pCR}$ for all analyses (C3M low $\leq 9.004 \mathrm{ng} / \mathrm{mL}$, high $>9.004 \mathrm{ng} / \mathrm{mL}$, C4M: low $\leq 40.91 \mathrm{ng} / \mathrm{mL}$, high $>40.91 \mathrm{ng} / \mathrm{mL}$ ) [30]. Using these cutoff values, $11.7 \%$ and $14.8 \%$ of patients had high C3M and C4M levels at baseline, respectively. Levels of serum degradation markers were measured in a cohort of 19 healthy females with a mean age of 51 years (C3M: Mean $3.9 \mathrm{ng} / \mathrm{mL}$, median $3.6 \mathrm{ng} / \mathrm{mL}$; C4M: Mean $28.2 \mathrm{ng} / \mathrm{mL}$, median $25.3 \mathrm{ng} / \mathrm{mL}$ ). With regard to changes in serum degradation markers, "no change" was defined as an increase $<20 \%$ or a decrease $<20 \%$.

All time-to-event endpoints were defined as the time (in months) from random assignment to the event; patients without an event were censored at the time of the last contact. Events for DFS were any loco-regional (ipsilateral breast or local/regional lymph nodes) recurrence of disease, any contralateral breast cancer, any distant recurrence of disease, any secondary malignancy or death as a result of any cause, whichever occurred first. OS was defined as the time since random assignment until death as a result of any cause [31]. Kaplan-Meier product limit method was used to estimate the time-to-event curves. The log-rank test was used to evaluate the univariate significance of the clinical, histological and blood-based parameters for the time-to-event endpoints. Cox proportional hazard models were constructed to evaluate the multivariate significance.

All reported p-values are two-sided; values $\leq 0.05$ were considered significant. Statistical analysis was performed using the SPSS program Version 21.0 (SPSS Inc., Chicago, IL, USA). The study was performed and the manuscript prepared according to the REporting recommendations for tumor MARKer prognostic studies (REMARK) criteria on reporting of biomarkers [32].

\section{Conclusions}

In the present study, we show that levels of collagen degradation markers in the serum of BC patients are higher than in healthy controls. Patients with elevated C3M and C4M levels were more likely to achieve pCR; however, high levels of CDM were also associated with worse clinical outcome. In summary, our results suggest that enhanced ECM remodeling reflected by serum degradation markers in early breast cancer is associated with more aggressive and proliferative biology. Potentially, 
the measurement of collagen degradation markers might help to identify patients in need of additional secondary adjuvant therapeutic strategies.

Author Contributions: Conceptualization, S.L., I.W., C.M., B.L., C.S. (Christine Solbach), T.K., F.M., V.N., C.S. (Christian Schem), E.S., M.U., N.W., M.A.K. and V.M.; methodology, S.L., I.W., C.M. and N.W.; software, S.L., B.L. and V.N.; validation, S.L., B.L., V.N. and V.M.; writing-original draft preparation, M.B.-P. and V.M.; writing-review and editing, M.B.-P., S.L., I.W., N.W., M.A.K., B.L., V.N. and V.M.; Project Administration, S.L., B.L. and V.N.

Funding: The clinical trial was funded by Celgene and Roche and this biomarker project by Nordic Bioscience.

Acknowledgments: The authors would like to thank Valentina Vladimirova from the German Breast Group for her assistance with the project.

Conflicts of Interest: MBP received lecture honoraria or consultant fees from Roche, Novartis, Eli Lilly, Eisai and Pfizer. VM received lecture honoraria from Amgen, AstraZeneca, Celgene, Daiichi, Eisai, Pfizer, Novartis, served as a consultant/advisor to Hexal, Roche, Pfizer, Amgen, Daiichi, Nektar and Eisai and received research grants from Roche, Novartis, Seattle Genetics and Pfizer. I.W. received honoraria from Roche, Pfizer, Novartis, Pierre Fabre Pharma and Daichii Sankyo. M.U.'s institution/employer has received lecture honoraria and consultant fees from Abbvie, Amgen, Astra Zeneca, Celgene, Daiji Sankyo, Eisai, Lilly, MSD Merck, Mundipharma, Myriad Genetics, Novartis, Pfizer, PUMA Biotechnology, Roche Pharma, Sanofi Aventis, TEVA Pharmaceuticals. FM received honoraria from Roche, AstraZeneca, Clovis, Celgene, Genomic Health, Tesaro, MSD, Pfizer, Eisai and served as a consultant or in an advisory role for MSD, Eisai, Amgen, Roche, AstraZeneca, Novartis, Curevac. C.So. reports personal fees and non-financial support from Olympus Europa, personal fees from Roche, personal fees and non-financial support from Mylan, personal fees from Pfizer, personal fees and non-financial support from Medtronic, personal fees from Astra Zeneca, outside the submitted work. T.K., C.Sc., C.M., B.L., V.N., S.L. and E.S. declare no conflict of interest. N.W. and M.A.K. are employees at Nordic Bioscience A/S. M.A.K. owns stocks at Nordic Bioscience A/S. The funders had no role in the design of the study; in the collection, analyses or interpretation of data; in the writing of the manuscript, and in the decision to publish the results.

\section{Appendix A}

Table A1. Clinical-pathological characteristics of patients in two arms.

\begin{tabular}{ccccc}
\hline \multirow{2}{*}{ Parameter } & \multicolumn{2}{c}{ Trastuzumab } & \multicolumn{2}{c}{ Lapatinib } \\
\cline { 2 - 5 } & No. & $\%$ & No. & $\%$ \\
\hline Tumor size & & & & \\
T1 & 10 & 13.0 & 8 & 10.3 \\
T2 & 39 & 50.6 & 37 & 47.4 \\
T3 & 14 & 18.2 & 23 & 29.5 \\
T4 & 14 & 18.2 & 10 & 12.8 \\
\hline Missing & 0 & & 2 & \\
Grading & & & & \\
G1 & 1 & 1.3 & 1 & 1.3 \\
G2 & 35 & 45.5 & 40 & 50.0 \\
G3 & 41 & 53.2 & 39 & 48.8 \\
\hline Clinical nodal & & & & \\
status & & & & \\
Positive & 44 & 57.1 & 46 & 59.0 \\
Negative & 33 & 42.9 & 32 & 41.0 \\
Missing & 0 & & 2 & \\
\hline pCR & & & & \\
Yes & 23 & 29.9 & 22 & 27.5 \\
No & 54 & 70.1 & 58 & 72.5 \\
\hline
\end{tabular}


Table A2. Analysis of survival and changes in serum levels of C3M/C4M.

\begin{tabular}{|c|c|c|c|c|c|}
\hline End Point & $\begin{array}{c}\text { Collagen } \\
\text { Degradation } \\
\text { Marker }\end{array}$ & Category & $\begin{array}{c}\text { 5-Year Rates } \\
(\%)\end{array}$ & HR (95\% CI), $p$-Values & $\begin{array}{c}\text { Log-Rank } \\
p \text {-Value }\end{array}$ \\
\hline DFS & $\mathrm{C} 3 \mathrm{M}$ & $\begin{array}{l}\text { No change * } \\
\text { Increase } \\
\geq 20 \% \\
\text { Decrease } \\
\geq 20 \%\end{array}$ & $\begin{array}{l}89.2 \\
80.9 \\
53.0\end{array}$ & $\begin{array}{c}\text { reference } \\
1.30(0.46-3.65) \\
p=0.620 \\
3.55(1.51-8.31) \\
p=0.004\end{array}$ & 0.005 \\
\hline OS & & $\begin{array}{l}\text { No change } \\
\text { Increase } \\
\geq 20 \% \\
\text { Decrease } \\
\geq 20 \%\end{array}$ & $\begin{array}{l}96.5 \\
83.8 \\
79.1\end{array}$ & $\begin{array}{c}\text { reference } \\
3.76(0.69-20.50) \\
p=0.127 \\
6.49(1.31-32.23) \\
p=0.022\end{array}$ & 0.037 \\
\hline DFS & C4M & $\begin{array}{l}\text { No change } \\
\text { Increase } \\
\geq 20 \% \\
\text { Decrease } \\
\geq 20 \%\end{array}$ & $\begin{array}{l}73.4 \\
83.3 \\
78.3\end{array}$ & $\begin{array}{c}\text { reference } \\
0.80(0.33-1.95) \\
p=0.623 \\
0.86(0.31-2.34) \\
p=0.765\end{array}$ & 0.872 \\
\hline OS & & $\begin{array}{l}\text { No change } \\
\text { Increase } \\
\geq 20 \% \\
\text { Decrease } \\
\geq 20 \%\end{array}$ & 83.5 & $\begin{array}{c}\text { reference } \\
1.54(0.41-5.73) \\
p=0.522 \\
1.58(0.38-6.62) \\
p=0.530\end{array}$ & 0.748 \\
\hline
\end{tabular}

* defined as an increase $<20 \%$ or decrease $<20 \%$.

Table A3. Serum levels of collagen degradation markers in healthy controls.

\begin{tabular}{cccc}
\hline Value & Age (Years) & C3M (ng/mL) & C4M2 (ng/mL) \\
\hline Mean \pm SD & $51 \pm 14.7$ & $3.9 \pm 1.1$ & $28.2 \pm 10.4$ \\
Median (range) & $53(31-78)$ & $3.6(2.6-7.1)$ & $25.3(18.3-58.6)$ \\
\hline
\end{tabular}

\section{References}

1. Bonnans, C.; Chou, J.; Werb, Z. Remodelling the extracellular matrix in development and disease. Nat Rev Mol. Cell Biol. 2014, 15, 786-801. [CrossRef] [PubMed]

2. Karsdal, M.A.; Nielsen, M.J.; Sand, J.M.; Henriksen, K.; Genovese, F.; Bay-Jensen, A.C.; Smith, V.; Adamkewicz, J.I.; Christiansen, C.; Leeming, D.J.; et al. Extracellular matrix remodeling: the common denominator in connective tissue diseases. Possibilities for evaluation and current understanding of the matrix as more than a passive architecture, but a key player in tissue failure. Assay Drug Dev. Technol. 2013, 11, 70-92. [CrossRef] [PubMed]

3. Bager, C.L.; Willumsen, N.; Leeming, D.J.; Smith, V.; Karsdal, M.A.; Dornan, D.; Bay-Jensen, A.C. Collagen degradation products measured in serum can separate ovarian and breast cancer patients from healthy controls: A preliminary study. Cancer Biomark. 2015, 15, 783-788. [CrossRef] [PubMed]

4. Willumsen, N.; Bager, C.; Karsdal, M.A. Matrix Metalloprotease Generated Fragments of Type VI Collagen Have Serum Biomarker Potential in Cancer-A Proof of Concept Study. Transl. Oncol. 2019, 12, $693-698$. [CrossRef] [PubMed]

5. Kehlet, S.N.; Sanz-Pamplona, R.; Brix, S.; Leeming, D.J.; Karsdal, M.A.; Moreno, V. Excessive collagen turnover products are released during colorectal cancer progression and elevated in serum from metastatic colorectal cancer patients. Sci. Rep. 2016, 6, 30599. [CrossRef] [PubMed]

6. Willumsen, N.; Bager, C.L.; Leeming, D.J.; Smith, V.; Christiansen, C.; Karsdal, M.A.; Dornan, D.; Bay-Jensen, A.C. Serum biomarkers reflecting specific tumor tissue remodeling processes are valuable diagnostic tools for lung cancer. Cancer Med. 2014, 3, 1136-1145. [CrossRef] [PubMed] 
7. Willumsen, N.; Bager, C.L.; Leeming, D.J.; Smith, V.; Karsdal, M.A.; Dornan, D.; Bay-Jensen, A.C. Extracellular matrix specific protein fingerprints measured in serum can separate pancreatic cancer patients from healthy controls. BMC. Cancer 2013, 13, 554. [CrossRef]

8. Lipton, A.; Leitzel, K.; Ali, S.M.; Polimera, H.V.; Nagabhairu, V.; Marks, E.; Richardson, A.E.; Krecko, L.; Ali, A.; Koestler, W.; et al. High turnover of extracellular matrix reflected by specific protein fragments measured in serum is associated with poor outcomes in two metastatic breast cancer cohorts. Int. J. Cancer 2018, 143, 3027-3034. [CrossRef]

9. Willumsen, N.; Bager, C.L.; Kehlet, S.N.; Dragsbaek, K.; Neergaard, J.S.; Hansen, H.B.; Bay-Jensen, A.C.; Leeming, D.J.; Lipton, A.; Christiansen, C.; et al. Excessive matrix metalloprotease-mediated degradation of interstitial tissue (type I collagen) independently predicts short-term survival in an observational study of postmenopausal women diagnosed with cancer. Oncotarget 2017, 8, 52501-52510. [CrossRef]

10. Kauppila, S.; Stenback, F.; Risteli, J.; Jukkola, A.; Risteli, L. Aberrant type I and type III collagen gene expression in human breast cancer in vivo. J. Pathol. 1998, 186, 262-268. [CrossRef]

11. Allinen, M.; Beroukhim, R.; Cai, L.; Brennan, C.; Lahti-Domenici, J.; Huang, H.; Porter, D.; Hu, M.; Chin, L.; Richardson, A.; et al. Molecular characterization of the tumor microenvironment in breast cancer. Cancer Cell 2004, 6, 17-32. [CrossRef] [PubMed]

12. Bergamaschi, A.; Tagliabue, E.; Sorlie, T.; Naume, B.; Triulzi, T.; Orlandi, R.; Russnes, H.G.; Nesland, J.M.; Tammi, R.; Auvinen, P.; et al. Extracellular matrix signature identifies breast cancer subgroups with different clinical outcome. J. Pathol. 2008, 214, 357-367. [CrossRef] [PubMed]

13. Bao, W.; Fu, H.J.; Jia, L.T.; Zhang, Y.; Li, W.; Jin, B.Q.; Yao, L.B.; Chen, S.Y.; Yang, A.G. HER2-mediated upregulation of MMP-1 is involved in gastric cancer cell invasion. Arch. Biochem. Biophys. 2010, 499, 49-55. [CrossRef] [PubMed]

14. Fatunmbi, M.; Shelton, J.; Aronica, S.M. MMP-9 increases HER2/neu expression and alters apoptosis levels in human mammary epithelial cells (HMEC). Breast Cancer Res. Treat 2012, 135, 519-530. [CrossRef] [PubMed]

15. Nami, B.; Wang, Z. HER2 in Breast Cancer Stemness: A Negative Feedback Loop towards Trastuzumab Resistance. Cancers (Basel) 2017, 9, 40. [CrossRef]

16. Giussani, M.; Merlino, G.; Cappelletti, V.; Tagliabue, E.; Daidone, M.G. Tumor-extracellular matrix interactions: Identification of tools associated with breast cancer progression. Semin. Cancer Biol. 2015, 35, 3-10. [CrossRef] [PubMed]

17. Dittmer, J.; Leyh, B. The impact of tumor stroma on drug response in breast cancer. Semin. Cancer Biol. 2015, 31, 3-15. [CrossRef]

18. Jansen, M.P.; Foekens, J.A.; van Staveren, I.L.; Dirkzwager-Kiel, M.M.; Ritstier, K.; Look, M.P.; Meijer-van Gelder, M.E.; Sieuwerts, A.M.; Portengen, H.; Dorssers, L.C.; et al. Molecular classification of tamoxifen-resistant breast carcinomas by gene expression profiling. J. Clin. Oncol. 2005, 23, 732-740. [CrossRef]

19. Farmer, P.; Bonnefoi, H.; Anderle, P.; Cameron, D.; Wirapati, P.; Becette, V.; Andre, S.; Piccart, M.; Campone, M.; Brain, E.; et al. A stroma-related gene signature predicts resistance to neoadjuvant chemotherapy in breast cancer. Nat. Med. 2009, 15, 68-74. [CrossRef]

20. Hess, K.R.; Anderson, K.; Symmans, W.F.; Valero, V.; Ibrahim, N.; Mejia, J.A.; Booser, D.; Theriault, R.L.; Buzdar, A.U.; Dempsey, P.J.; et al. Pharmacogenomic predictor of sensitivity to preoperative chemotherapy with paclitaxel and fluorouracil, doxorubicin, and cyclophosphamide in breast cancer. J. Clin. Oncol. 2006, 24, 4236-4244. [CrossRef]

21. Mazouni, C.; Arun, B.; Andre, F.; Ayers, M.; Krishnamurthy, S.; Wang, B.; Hortobagyi, G.N.; Buzdar, A.U.; Pusztai, L. Collagen IV levels are elevated in the serum of patients with primary breast cancer compared to healthy volunteers. Br. J. Cancer 2008, 99, 68-71. [CrossRef] [PubMed]

22. Revert, F.; Revert-Ros, F.; Blasco, R.; Artigot, A.; Lopez-Pascual, E.; Gozalbo-Rovira, R.; Ventura, I.; Gutierrez-Carbonell, E.; Roda, N.; Ruiz-Sanchis, D.; et al. Selective targeting of collagen IV in the cancer cell microenvironment reduces tumor burden. Oncotarget 2018, 9, 11020-11045. [CrossRef] [PubMed]

23. Harisi, R.; Jeney, A. Extracellular matrix as target for antitumor therapy. Onco. Targets Ther. 2015, 8, 1387-1398. [CrossRef] [PubMed]

24. Witzel, I.; Loibl, S.; von Minckwitz, G.; Eidtmann, H.; Fehm, T.; Khandan, F.; Schmatloch, S.; Hauschild, M.; Bischoff, J.; Fasching, P.A.; et al. Predictive value of HER2 serum levels in patients treated with lapatinib or 
trastuzumab-A translational project in the neoadjuvant GeparQuinto trial. Br. J. Cancer 2012, 107, 956-960. [CrossRef] [PubMed]

25. Untch, M.; Loibl, S.; Bischoff, J.; Eidtmann, H.; Kaufmann, M.; Blohmer, J.U.; Hilfrich, J.; Strumberg, D.; Fasching, P.A.; Kreienberg, R.; et al. Lapatinib versus trastuzumab in combination with neoadjuvant anthracycline-taxane-based chemotherapy (GeparQuinto, GBG 44): A randomised phase 3 trial. Lancet. Oncol. 2012, 13, 135-144. [CrossRef]

26. Untch, M.; von Minckwitz, G.; Gerber, B.; Schem, C.; Rezai, M.; Fasching, P.A.; Tesch, H.; Eggemann, H.; Hanusch, C.; Huober, J.; et al. Survival Analysis After Neoadjuvant Chemotherapy With Trastuzumab or Lapatinib in Patients With Human Epidermal Growth Factor Receptor 2-Positive Breast Cancer in the GeparQuinto (G5) Study (GBG 44). J. Clin. Oncol. 2018, 36, 1308-1316. [CrossRef] [PubMed]

27. Dam, E.B.; Byrjalsen, I.; Karsdal, M.A.; Qvist, P.; Christiansen, C. Increased urinary excretion of C-telopeptides of type II collagen (CTX-II) predicts cartilage loss over 21 months by MRI. Osteoarthr. Cartil. 2009, 17, 384-389. [CrossRef]

28. Veidal, S.S.; Vassiliadis, E.; Barascuk, N.; Zhang, C.; Segovia-Silvestre, T.; Klickstein, L.; Larsen, M.R.; Qvist, P.; Christiansen, C.; Vainer, B.; et al. Matrix metalloproteinase-9-mediated type III collagen degradation as a novel serological biochemical marker for liver fibrogenesis. Liver Int. 2010, 30, 1293-1304. [CrossRef]

29. Veidal, S.S.; Karsdal, M.A.; Nawrocki, A.; Larsen, M.R.; Dai, Y.; Zheng, Q.; Hagglund, P.; Vainer, B.; Skjot-Arkil, H.; Leeming, D.J. Assessment of proteolytic degradation of the basement membrane: a fragment of type IV collagen as a biochemical marker for liver fibrosis. Fibrogenesis Tissue Repair 2011, 4, 22. [CrossRef]

30. Budczies, J.; Klauschen, F.; Sinn, B.V.; Gyorffy, B.; Schmitt, W.D.; Darb-Esfahani, S.; Denkert, C. Cutoff Finder: A comprehensive and straightforward Web application enabling rapid biomarker cutoff optimization. PLoS ONE 2012, 7, e51862. [CrossRef]

31. Hudis, C.A.; Barlow, W.E.; Costantino, J.P.; Gray, R.J.; Pritchard, K.I.; Chapman, J.A.; Sparano, J.A.; Hunsberger, S.; Enos, R.A.; Gelber, R.D.; et al. Proposal for standardized definitions for efficacy end points in adjuvant breast cancer trials: the STEEP system. J. Clin. Oncol. 2007, 25, 2127-2132. [CrossRef] [PubMed]

32. McShane, L.M.; Altman, D.G.; Sauerbrei, W.; Taube, S.E.; Gion, M.; Clark, G.M. REporting recommendations for tumour MARKer prognostic studies (REMARK). Br. J. Cancer 2005, 93, 387-391. [CrossRef] [PubMed]

(C) 2019 by the authors. Licensee MDPI, Basel, Switzerland. This article is an open access article distributed under the terms and conditions of the Creative Commons Attribution (CC BY) license (http://creativecommons.org/licenses/by/4.0/). 